\title{
Worksheet for Application of Word Square Learning Models at Publik Junior High School Number I Kapur IX District
}

\author{
$1^{\text {st }}$ Sri Rahayu* \\ Social Sciences Education STKIP PGRI West \\ Sumatra, Padang, Indonesia \\ sri@stkip-pgri-sumbar.ac.id \\ $2^{\text {nd }}$ Deswa Yodi Eka Putra \\ Student STKIP PGRI West Sumatra, \\ Padang, Indonesia
}

\author{
$3^{\text {rd }}$ Harisnawati \\ Social Sciences Education STKIP PGRI West \\ Sumatra, Padang, Indonesia
}

$4^{\text {th }}$ Anggia Ramadhani

Student STKIP PGRI West Sumatra,

Padang, Indonesia

\begin{abstract}
This research is motivated by negative activities that occur in the learning process such as students often in and out, telling stories, disturbing friends in Public Junior High School Number I (Sekolah Menengah Pertama Negeri /SMPN) I Kapur IX District. The purpose of this study is to find out the application of the word square learning model accompanied by student worksheet to the learning activities of VII2 graders of Social Sciences for Even 2018/2019 academic year. The method used in this research is descriptive qualitative type. The subjects in this study were students of class VII2 of 26 students. The
\end{abstract}

\section{INTRODUCTION}

Education is very important in human life, to realize the ideal human being, which is aspired to require direction, guidance and education. Education has a role in making humans into the ideal human figure, that is, human beings with all their dignity. Education also has an important role in providing knowledge, skills, and a certain expertise to individuals or groups to develop their potential in the era of advancement in science and technology (science and technology). According to John Dewey, a pragmatic and dynamic American philosophy of education, education is a process of forming intellectual and emotional fundamental abilities towards the nature of fellow humans [1]. In education, educators and students cannot be technique of collecting observation data directly with sheets uses observation sheets. The results of this study show positive student activity in the learning process compared before using the work square learning model accompanied by student worksheet. The positive activity of students increases like listening, asking, reading, writing and enthusiasm in learning compared to learning before using the work square learning model accompanied by student worksheet.

Keywords-Activity, Word Square, student worksheet, Social Studies Learning

released. Educators act as educators who function to provide knowledge to students through learning. The role ofteacher in education is very important in learning both physically and psychologically and socially. According Sukmadinata [2] states that "the task of the teacher at the school a lot, they must make a systematic teaching plan, detailed, for each lesson the gives. In essence students may only study well if the teacher has prepared a conducive environment for them to learn. Student learning activities which can be observed indirectly, while the learning process which is an internal process of students can not be observed, but can be understood by the teacher. Educational programs in schools including tutoring service programs can be integrated with subjects so that the educational 
process in schools will be more meaningful in accordance with the needs of students and the needs of the community and development.

Teachers are not only required to behave professionally in carrying out their duties but teachers can also actively involve students both physically and mentally and socially students in the learning process take place. Learning is a process where individuals can change their behaviour to a better one, according to Sudjana [3] learning is a process of seeing, observing, and understanding something. To achieve success in learning activities, there are several components that must be developed by the teacher, namely the objectives, materials, strategies, and evaluation of learning. each component is interrelated and influences one another. Therefore, to get good and maximum learning outcomes, good activities in learning are needed. The basic needs that must be met by students in achieving learning outcomes. The expected learning outcome is the realization of qualified human beings who have spiritual, religious, self-control, personality, intelligence, noble character, and good life skills in society.

Based on the results of observations made at SMPN 1 Kapur IX District Lima Puluh Kota in class VII 2 it was found that students caused more negative learning activities such as students often going in and out of class, when the teacher wanted to explain the learning material there must be students coming out enter, talk to their classmate with a conversation that is not in accordance with the topic of learning material. Annoy their friends by throwing objects on the table or head. When asked why acting like that students answer because learning is boring, and added to the learning situation during the day. This does not make students focus on learning. This can be seen from the learning outcomes of Grade VII 2 students who are on average incomplete. The following is the midterm test scores of Grade VII 2 students of SMPN 1, Kapur IX District, Lima Puluh Regency in the academic year 2018/2019.

Table 1. Middle Semester Deuteronomy Values

\begin{tabular}{|c|c|c|c|}
\hline No & Percentage & Student & Value Range \\
\hline 1 & $7-27$ & 0 & $0 \%$ \\
\hline 2 & $28-48$ & 1 & $4 \%$ \\
\hline 3 & $49-69$ & 12 & $46 \%$ \\
\hline 4 & $70-90$ & 11 & $42 \%$ \\
\hline \multirow[t]{2}{*}{5} & $\geq 91$ & 2 & $8 \%$ \\
\hline & Amount & 26 & $100 \%$ \\
\hline
\end{tabular}

Based on the Minimum Completeness Criteria (MCC) set by the school that is 70 for social studies class VII. based on table 1 obtained by $50 \%$ of participants declared incomplete in social studies subjects. This can be stated that the learning activities of students have not been indicated successful, this can be seen from the results of learning that is still incomplete. In this case the teacher must try to improve the learning style again and apply learning models and methods that can support student learning activities in the classroom so that they get the desired learning outcomes. The learning model applied must be in accordance with the characteristics of junior high school students. Usually, junior high school students are still in the process of growth and development and they are very interested in playing method but there is still an element of learning. Many learning models that are games, one of them is Word Square learning model.

According to [4] Word Square learning model is a model of the development of lecture methods that are enriched and oriented to the activeness of students in learning. This model is also a model that combines the ability to answer 
questions with carefulness in matching answers to answer boxes similar to filling in "Crosswords" but the difference is that the answer is already there but is disguised by adding additional boxes with arbitrary letters or numbers. The special thing about this learning model can be practised for all subjects, only how the teacher can program a number of selected questions that can stimulate students to think effectively. The purpose of deceptive letters / numbers is not to make it difficult for students but to practice being careful and critical. According [5]Word Square learning model is a learning model that uses boxes in the form of crosswords as a tool in conveying teaching material in the teaching and learning process. Word Square learning model was chosen because this learning model has elements of a game or game in it. This model is also assisted by an answer instrument or student worksheet tool such as a crossword puzzle but the answers are already there and match them with other letters in the box.

Student Worksheet is a set of materials or a place to make work or assignments of individuals or groups that can provide reinforcement concepts through exercises so that students can succeed in accordance with learning objectives. In this case, the student worksheet is used in accordance with the steps in the Word Square learning model in the form of questions with answers provided in the form of boxes disguised by other letters. With the application of the Word Square learning model accompanied by student worksheet, it can increase the learning activities of students because here students are directly involved in listening to material, reading, writing directly in student worksheet so that it can lead to positive learning activities in the classroom and can improve learning outcomes later.

According to Diedrich quoted by [6], the activities or activities of students can be classified as follows: (a) visual activities, for example reading, observing pictures, observing experiments, observing demonstrations and exhibitions, observing others working or playing ; (b) moral activities, expressing a fact or principle, linking an event, asking a question, giving a suggestion, expressing an opinion, conducting an interview, discussing and interrupting it; (c) listening activities, for example listening to the presentation of material, listening to conversations or group discussions, listening to games, listening to the radio, listening to music and speeches; (d) writing activities, such as drawing, making graphics, making maps, diagrams, patterns and making charts; (e) motor activities, which include among others: conducting experiments, selecting equipment, conducting exhibitions, making models, conducting games, dancing, gardening and theme activities; (f) mental activities, for example: reflecting, remembering, solving problems, analyzing factors, looking at relationships and making decisions; and $(\mathrm{g})$ emotional activities, such as paying interest, differentiating, feeling bored, happy or excited, excited, passionate, brave, calm and nervous. Based on the description above, the researcher is interested in researching "The Implementation of the Word Square Learning ModelIn Join student worksheet Against Student Learning Activities".

\section{METHOD}

The approach used in this research is a qualitative approach with descriptive type. Descriptive is a study in the form of words, pictures, interviews, field notes, photos, personal documents, notes or memos, and other official documents that guide the research so that when in the field researchers get more relevant information about the data researchers want to obtain from informants who will become evident, such as official documents obtained in the field as a result of interviews, but also perpetuate them with photos or pictures obtained while in the field [7]. The objects in this study were all students of class VII 2, as many as 26 students. The type of data used is primary data and secondary data. Data collection methods are direct observation and study of documents. Data analysis in this study uses the method of Miles and Huberman, data analysis is to break down and process raw data into data that is interpreted and understood more specifically and recognized in the same scientific perspective so that the right processing data can be generated [8]. This research is in 
SMPN 1 Kapur IX District, Lima Puluh Kota Regency.

\section{RESULTS AND DISCUSSION}

This study was conducted as many as 5 meetings. Before conducting research, researchers prepared a Learning Implemen tation Plan (LIP) of the learning process in the class of researchers preparing RPP according to the work square model, with BC 3.3 Understanding the concept of interaction between humans and space so as to produce various economic activities (production, distribution, consumption, demand and supply) and interaction between spaces for the sustainability of Indonesia's economic, social and cultural life.

At the first meeting with the material economic activity with its Indicator 3.1.1 Explain the notion of production, 3.1.2 Explain the purpose of production, 3.1.2 Explain the factors that affect production, teachers enter the classroom and students do greetings and prayers, the teacher validates students one by one with time is approximately 10 minutes, the teacher explains the learning model, the teacher explains the learning objectives, after that the teacher attaches a picture of production on the blackboard and asks students to ask about the picture placed at this stage the student's activities observe and ask about things related to the picture for 10 minute. Student learning activities are observing pictures of people planting rice attached to the writing board. After students analyze the teacher and students give questions related to the picture with questions from the educator what picture is posted on the front, BeningPermata students answer that it is people planting rice, educators continue the question which economic activity? Does the production, distribution or consumption activities, students Laura Anggraini Answering include production activities, after going through the question and answer intro between the educator and the students, the educator continues to deliver the material through the lecture method by delivering the material according to the achievement indicators for approximately 30 minutes, at this stage, the activity students listen to what the teacher has to say and write things that are considered important, after students understand the material the teacher gives student worksheet to each student, at this stage students are asked to read material in student worksheet that students have not yet understood, after that the teacher gives instructions on how to answer questions and scoring in student worksheet, student worksheet scoring for each material differs depending on many questions, at 20 material economic activity meetings, students are only allowed to answer questions in accordance with indicators of production activities? Scoring uses the formula of the number of correct million divided by the number of questions. Furthermore students participate in answering student worksheet with 20 minutes of answering time, the enthusiasm of students in completing student worksheet is quite high because they have only found ways of learning such as filling out puzzles in learning. Student worksheet here serves to train students with a variety of test questions and questions issued in student worksheet likely to appear when taking scores of learning outcomes, after answering the teacher checking the student worksheet answers of students and very the students to listen to the grades given were enthusiastic by the teacher, at the end lesson teacher asks if everyone understands the material that day, students and the teacher concludes the subject matter, the teacher gives the next sub-indicator to read at home with indicators of distribution and consumption activities, the teacher greets.

At the second meeting with indicators 3.1.3 Explain the meaning of distribution, 3.1.4 Explain the purpose of distribution, 3.1.5 Explain the meaning of consumption and 3.1.6 Explain consumption activities in economic households held two meetings. As usual, teachers enter class, pray and attendance and ask students' readiness for learning, after the need for stationery is issued, educators attach pictures of distribution and consumption activities in front with pictures of two cars that lead from villages to cities and pictures of people eating junk food, Educators ask what kinds of activities of the left picture? Next, the educator asks what is meant by distribution and consumption. Students Neza Maula El Rahma answered that distribution delivered goods, while consumption used the goods, then 
educators asked whether only goods were to be distributed or consumed ?, Bening Permata Eliza students answered not only goods but services were also forms of economic activity, services could be distributed and spent. Furthermore, educators deliver material approximately 30 minutes, after that educators give student worksheet to students and ask them to the comprehend to read them for understanding the indicators of distribution and consumption activities. Furthermore, students are told to answer questions in the student worksheet continued from the previous meeting which is about production activities. Educators give 20 minutes to answer and leave it to the teacher to be examined. After filling the student worksheet and scoring, the teacher submits the score obtained by each student. After that the teacher and students together conclude the learning material that day, and the teacher asks them to read the next indicator which is demand and supply. Educators say hello and get out of class.

At the third meeting with indicators 1.3.1 Explaining the definition of demand, 1.3.2 Explaining the factors affecting demand, 1.3.3 explaining the law of demand, 1.3.4 explaining the definition of supply, 1.3.5 explaining the factors influencing supply and 1.3.6 explaining the legal offer . As usual, the teacher enters the classroom validates the students and instructs the students to issue tools related to social studies learning, then the teacher starts to attach the activity of buying and selling on the whiteboard, the teacher asks what process in this picture ?, students Abdul Sahal answers buying goods are to fulfil the needs of life, the teacher answered whether there is another answer, Wulandari students answered that it was a demanding activity in terms of the buyer, the buyer purchased the goods to fulfil his needs were met, the teacher answered is that only a demand activity?, RaudhahHarfel said no, there was not only a process of demand from consumers but also offers from traders. Educators answered theyall answer was true. So our material today is supply and demand activities. Furthermore, the teacher explains the learning objectives and the teacher conveys material requests and offers with the lecture method that is heard by students, this activity takes 40 minutes. After the activity the teacher gives student worksheet and students are asked to re-read the differences in demand and supply as well as differences in demand and supply graphs and how to make these graphs. After that the teacher was asked to fill in student worksheet as many as 15 questions over a period of 20 minutes, and after being done directly examined by the teacher and conveyed the scores of each student. And for the closing activity with 10 minutes the students and teachers together conclude the learning material and the teacher and students together say hello.

At the fourth meeting, with indicator 1.1.1 Explaining market functions, 1.1.2. explain the types of markets and 1.1.3 explain the meaning of prices. As is the case still alike with the previous meeting where the teacher enters the classroom, validates students and checks equipment and needs for social studies, then the teacher attaches pictures of people selling primary needs in the market. Then the teacher asks what picture is this? DefkyDewaAnandes said that it was an interaction in the market, another student AinilMardiyah said it was exchanging process, Della Septiani students answered the process of bargaining in the market, Bodi Yolanda Reski'ssaid it was a place to buy kitchen materials, RaudhahHarfel said it was a place to exchange goods/services/money, Wulandari states that it is a traditional market by selling cooking utensils, Laura Anggrainisaid it was a market with a price determination, there are many answers from students convey that what the teacher is conveyed is all true, this picture is the market, the market where buyers and sellers meet, place of price formation, place of sale, place of trade so who knows what the market is? Raudhah answered that a market is a place for people to buy and sell in units of time. After that the teacher conveys all indicators through the lecture method with 40 minutes because the material about the market is quite dense and there are quite a lot of types of markets, and making a balance price chart is quite difficult. The teacher gives a question in front of the whiteboard that is a question with the number of items requested and the number of items offered at various specified prices. The teacher tells one of the students to make a price balance graphic on the board, who answers this question BeningPermata students, he makes a 
balance price chart. And the graphics made are correct. The key conveyor of making a balance price chart is to combine how to make a demand graph and supply graph looking for the intersection of the line graph then that is the price balance or can be called a market price. After the indicators are delivered, the teacher gives student worksheet and students are asked to answer 15 questions about the market and prices in the student worksheet for 20 minutes. After students complete, the answers and the teacher scores the answers then submit the results of the answers to each student before the learning material closes. Furthermore, the teacher and students together conclude the learning material and close the class and submit to the next meeting an evaluation will be held.

At the fifth meeting the students were evaluated with indicators of production, distribution, consumption, activity demand, supply, market and prices with as many as 25 questions with scoring techniques that are correct 4 and false 0 with objective question forms with four choices. When evaluations are held each student is prohibited from copying and chairs and tables arranged one by one.
Based on the results of the study found that in the first meeting with the material production activities obtained student learning activities such as listening to material from the teacher as many as 26 people, asking as many as 4 people, reading activities as many as 17 people, writing as many as 26 people and at this first meeting negative activities have begun to decrease because students get a new way of learning. In the second meeting with distribution and consumption materials, it was found that students' learning activities such as listening to material from the teacher were 26 people, asking questions as many as 6 people, reading activities were 20 people, writing as much as 26 people. In the third meeting with demand and supply material obtained learning activities of students listening to the material from the teacher as many as 26 people, asking as many as 5 people, reading activities as many as 22 people, writing as much as 26 people and at the fourth meeting with market material and prices obtained student learning activities such as listening material from 26 teachers, asking 8 people, reading activities 22 people, writing as many as 26 people and recapitulation can be seen as follows:

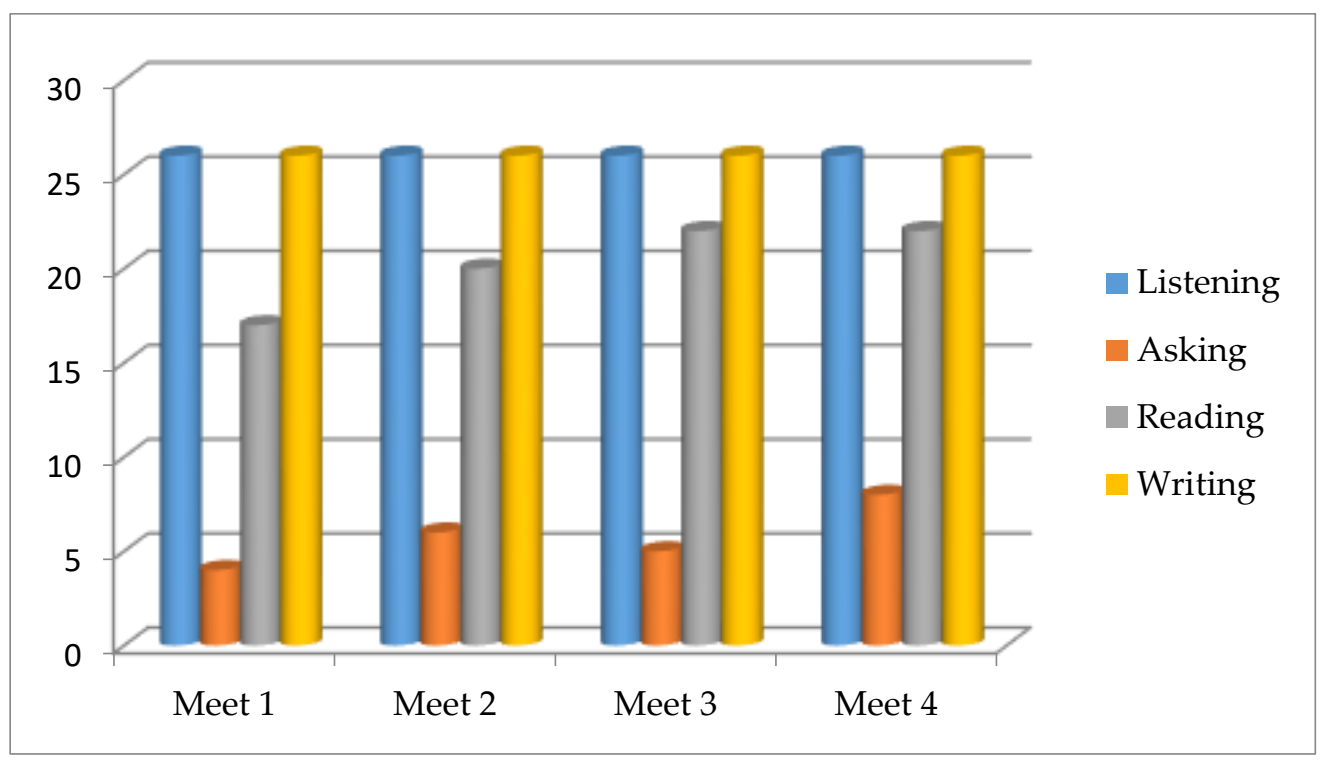

Figure 1. Recapitulation of Student Activities Source: Primary Data 


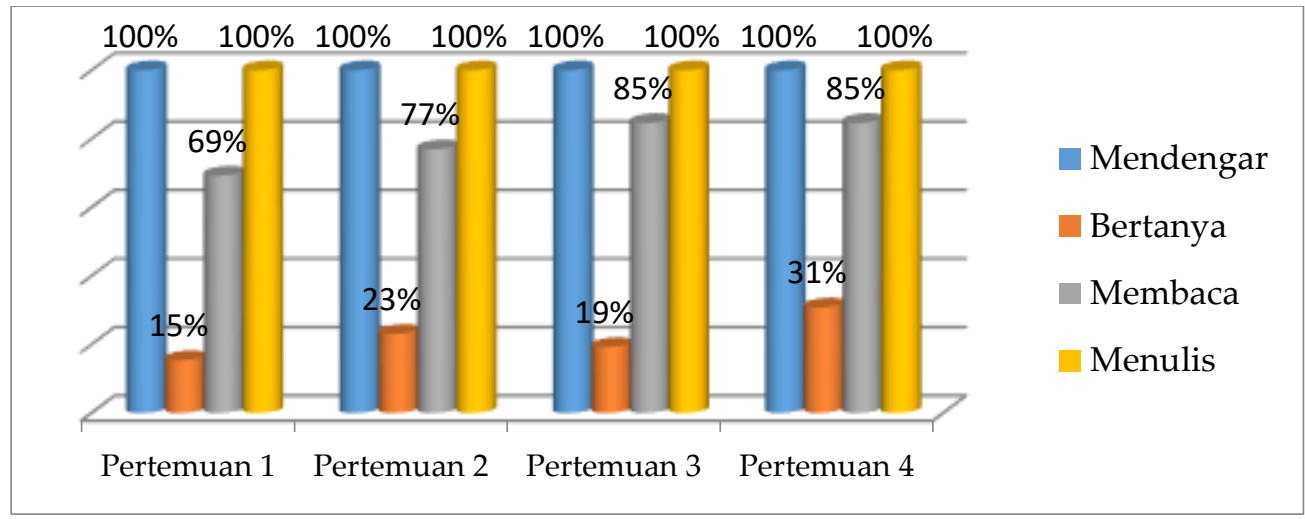

Figure2. Percentage of Learning Activities Source: Primary data

Based on the data obtained it can be concluded that the learning activities of students hear as much as $100 \%$, ask $22 \%$, read $72 \%$, and write $100 \%$, this proves that the application of this word square model has a positive impact on students and it turns out after being evaluated by giving questions according to the material delivered by applying the word square learning model also increased and the average reaching the KKM limit set by the school can be seen in the following table:

Table 2.Student Grades

\begin{tabular}{llll}
\hline No & Percentage & Student & Value Range \\
\hline 1 & $7-27$ & 0 & $0 \%$ \\
\hline 2 & $28-48$ & 0 & $0 \%$ \\
\hline 3 & $49-69$ & 1 & $4 \%$ \\
\hline 4 & $70-90$ & 19 & $73 \%$ \\
\hline 5 & $\geq 91$ & 6 & $23 \%$ \\
\hline & Amount & 26 & $100 \%$ \\
\hline
\end{tabular}

Based on the values obtained, the data states that only 1 person did not get a score that was unsatisfactory and as many as 25 students declared complete on the material. This proves that by applying the word square learning model can change learning activities by so as to increase student learning outcomes by $96 \%$. So it can be concluded that the application of the word square learning model along with student worksheet can improve student learning activities and improve student learning outcomes.

The results of this study were analyzed using Behavioristic theory, according to this theory learning is input in the form of stimulus and output or in the form of response. Stimulus is what is given by the teacher to students to help student learning, while the response is the reaction of students to the stimulus provided by the teacher (Budiningsih, 2004). In this study, the stimulus given by the teacher using the Word Square model in Join student worksheet students were asked to fill in the words in the boxes provided so that attracting students' responses to fill in these boxes made activities in listening, asking questions, answering high and learning outcomes were high.

\section{CONCLUSIONS}

Based on the research conducted can be concluded (1) the application of word square learning model can lead to positive student learning activities and increase that are listening $100 \%$, asking $22 \%$, reading $72 \%$, and writing 
$100 \%$. (2) word square learning model can also improve student learning outcomes by $96 \%$ from before applying the word square learning model. (3) word square learning model along with student worksheet can increase student learning activities and improve student learning outcomes.

\section{ACKNOWLEDGMENTS}

The writers thank those who involved in writing this article.

\section{REFERENCES}

[1] Z. Syafril, \& Zen. (2012). Pengantar Pendidikan. Padang: Sukabima Press.

[2] Aliwanto. (2017). Analisis Aktivitas Belajar siswa. Jurnal Konseling Gusjigang, 3(1), pp. 64-71.
[3] E. Nurdyansyah, \& Fahyuni. (2016). Inovasi Model Pembelajaran Sesuai kurikulum 2013 ( $\left.1^{\text {st }} \mathrm{ed}\right)$. Sidoarjo: Nizamia Learning Center.

[4] B. Kurniasih, I., \& Sani. (2015).Ragam Pengembangan Model Pembelajaran untuk Peningkatan Profesionalitas Guru. Jakarta: Kata Pena.

[5] Istarani. (2014).58 Model Pembelajaran Inovatif. Medan: Media Persada.

[6] Sardiman. (2006).Interaksi dan Motivasi Belajar Mengajar. Jakarta: PT Raja Grafindo Persada.

[7] J. Moleong. (2010). Metode Penelitian Kualitatif. Bandung: Remaja Rosdakarya.

[8] Sugiyono. (2012). Metodologi Penelitian Kualitatif untuk Ilmu-ilmu Sosial. Jakarta: Sulemba Humanika. 